\title{
Multiple myeloma complicated with pseudomonas endocartiditis
}

\author{
Mieloma múltiplo complicado com endocardite infecciosa por pseudomonas
}

\author{
Juliana Todaro ${ }^{1}$, Patrícia Weinschenker Bollmann ${ }^{1}$, Amit Nussbacher $^{1}$, Luis Fernando Aranha Camargo ${ }^{1}$, \\ Bento Fortunato Cardoso dos Santos ${ }^{1}$, Daniel Alvarenga ${ }^{1}$, Laercio Alberto Rosemberg ${ }^{1}$, \\ David Costa de Souza Le Bihan ${ }^{1}$, Cláudio Henrique Fischer ${ }^{1}$, Auro del Giglio ${ }^{1}$
}

\begin{abstract}
Patients diagnosed with multiple myeloma are more susceptible to infections which are the major causes of morbidity and mortality associated to this disease. The main infectious agents involved are Gram-positive bacteria. However, after chemotherapy an increase in the incidence of Gram-negative strains is observed. These bacteria are also responsible for most cases of urinary tract infections. Here is reported a rare case in a 73-year-old man with multiple myeloma who developed endocarditis due to pseudomonas.
\end{abstract}

Keywords: Multiple myeloma; Endocarditis; Pseudomonas; Case reports

\section{RESUMO}

Pacientes diagnosticados com mieloma múltiplo são mais suscetíveis a infecções, que é a principal causa de morbidade e mortalidade associadas a essa doença. Os principais agentes infecciosos envolvidos são as bactérias Gram-positivas, mas, após a quimioterapia, pode haver aumento na incidência de Gram-negativos, que são responsáveis, na maioria dos casos, por infecções do trato urinário. Assim, descrevese um raro caso de um paciente de 73 anos de idade, com mieloma múltiplo diagnosticado com endocardite por pseudomonas.

Descritores: Mieloma múltiplo; Endocardite; Pseudomonas; Relatos de casos

\section{INTRODUCTION}

Multiple myeloma (MM) is a malignant plasma cell disorder that is characterized by the secretion of a monoclonal immunoglobulin in the blood and/or urine (M protein). Patients with MM are more susceptible to infections, which are the major causes of morbidity and mortality associated to this disease ${ }^{(1)}$. The immunosuppression seen in those patients occurs by reductions in functional antibodies as well as in granulocytes activity and complement release ${ }^{(2)}$. Infections are higher within first months after diagnosis and among patients with renal insufficiency ${ }^{(2,3)}$. Gram-positive microorganisms are the major causative agents, however, after chemotherapy an increase in the frequency of Gram-negative bacteria is observed being these agents responsible for cases of pneumonias and urinary tract infections ${ }^{(2,3)}$.

Despite the high incidence of infections, endocarditis is rare and often caused by Gram-positive bacteria ${ }^{(4)}$. This paper reports a case of infective endocarditis (IE) in mitral valve caused by Pseudomonas aeruginosa in a patient with $\mathrm{MM}$, and who were receiving chemotherapy.

\section{CASE REPORT}

A 73-year-old man reported pain and increase in the volume of the right lower limb. He was diagnosed three years earlier with IgG kappa MM, had stage IIIA of the Durie Salmon Staging (DSS), stage I of the International Staging System (ISS), multiple comorbidities (systemic arterial hypertension, diabetes mellitus and chronic atrial fibrilation). He presented fever for one day after having received for 20 days the second cycle of velcade-melphalanprednisone as third line scheme, that was followed by the increase in the volume of the right lower limb.

The patient had blood pressure of $100 \times 70 \mathrm{mmHg}$, irregular pulse of $120 \mathrm{bpm}, 90 \% \mathrm{O}_{2}$ saturation, and temperature of $38^{\circ} \mathrm{C}$. He was pale $+/ 4$, and had no signs

\footnotetext{
'Hospital Israelita Albert Einstein - HIAE, São Paulo (SP), Brazil.

Corresponding author: Juliana Todaro - Oncology Center of Hospital Israelita Albert Einstein - Avenida Albert Einstein, $627 / 701$ - Morumbi - Zip code: $05651-901$ - São Paulo (SP), Brazil - Phone: (55 11) 2151-1233 -E-mail: jutodaro@uol.com.br

Received on: Nov 25, 2011 - Accepted on: Oct 30, 2012
} 
of jaundice, non-palpable lymph nodes, no hemorrhages or petechiae. His heart auscultation revealed $++/ 6$ holosystolic murmur audible in mitral focus with radiation to axilla. At auscultation of the chest no adventitious sounds were heard. The patient had a flabby and painless abdomen, edema and hyperemia in the right lower limb, and fever (Figure 1).

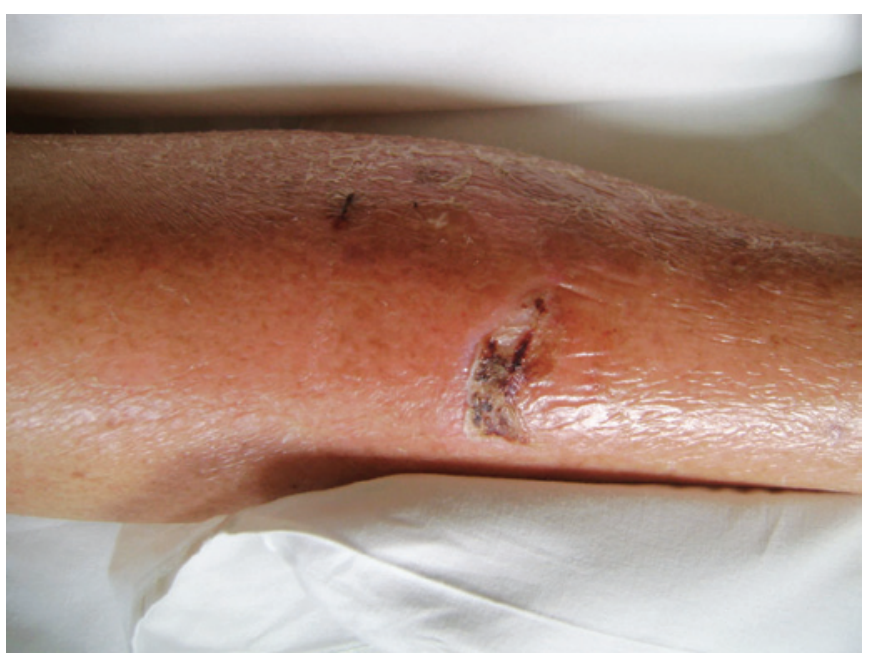

Figure 1. Right lower limb with edema and hyperemia

The chest radiography showed discrete signs of pulmonary congestion and normal cardiac area. The electrocardiogram was compatible with the atrial fibrillation. The blood count showed hemoglobin $11.8 \mathrm{~d} / \mathrm{L}$, plalelets $137,000 \mathrm{uL}$, white blood count $6,600 \mathrm{uL}$ with $7 \%$ of rods, $83 \%$ segmented, $7 \%$ lymphocytes and $1 \%$ monocytes. Laboratory tests showed C-reactive protein of $53.9 \mathrm{mg} / \mathrm{L}(0-3 \mathrm{mg} / \mathrm{L})$, creatinine value of $1.37 \mathrm{mg} / \mathrm{dL}$, and urea of $100 \mathrm{mg} / \mathrm{dL}$ (Table 1 ).

A deep venous color Doppler ultrasound in the lower limbs was normal. The echocardiogram disclosed important dilatation of left atrium, being mild for the right atrium and discrete for left ventricle. In addition, a mild degree left ventricular dysfunction was observed because of diffuse hypokinesis, asynchrony septal movement, and mitral valve thickness with calcifications, a preserved opening and an important regurgitation. A mobile filament image was observed measuring approximately $1 \mathrm{~cm}$ attached to the posterior leaflet, which suggested an infected vegetation (Figure 2). The patient was treated with ciprofloxacin and daptomycin at the intensive care unit.

After 12 hours results from blood culture reported the growing of a no resistant Pseudomonas aeruginosa, so ceftazedime was added to the treatment.
Table 1. Laboratory tests performed when the patient was admitted

\begin{tabular}{lc}
\hline Laboratory parameters & Values \\
\hline Hemoglobin & $11.8 \mathrm{~g} / \mathrm{dL}$ \\
Hematocrit & $37,5 \%$ \\
Leukocytes & $6.600 \mathrm{LL}$ \\
Rots & $7 \%$ \\
Neutrophils & $83 \%$ \\
Eosinophils & $0 \%$ \\
Basophils & $0 \%$ \\
Lymphocytes & $7 \%$ \\
Plalelets & $137.000 \mu \mathrm{L}$ \\
PCR & $53.9 \mathrm{mg} / \mathrm{L}$ \\
DHL & $921 \mathrm{U} / \mathrm{L}$ \\
D-dimer & $315 \mathrm{ng} / \mathrm{mL}$ \\
Fibrinogen & $444 \mathrm{mg} / \mathrm{dL}$ \\
TP (AP) & $30 \%$ \\
TTPA & $29 \mathrm{seg}$ \\
Urea & $100 \mathrm{mg} / \mathrm{dL}$ \\
Creatinine & $1,37 \mathrm{mg} / \mathrm{dL}$ \\
Sodium & $143 \mathrm{mEg} / \mathrm{L}$ \\
Potassium & $3.3 \mathrm{mEg} / \mathrm{L}$ \\
Calcium & $1.04 \mathrm{mEg} / \mathrm{L}$ \\
Magnesium & $1.1 \mathrm{mEg} / \mathrm{L}$ \\
Bicarbonate & $21.5 \mathrm{mEg} / \mathrm{L}$ \\
Arterial lactate & $26 \mathrm{mg} / \mathrm{dL}$ \\
Glucose & $91 \mathrm{mg} / \mathrm{dL}$ \\
TGO & $20 \mathrm{U} / \mathrm{L}$ \\
TGP & $31 \mathrm{U} / \mathrm{L}$ \\
Ilbumin & $2.2 \mathrm{~g} / \mathrm{dL}$ \\
Igilirubin & $0.9 \mathrm{mg} / \mathrm{dL}$ \\
\hline
\end{tabular}
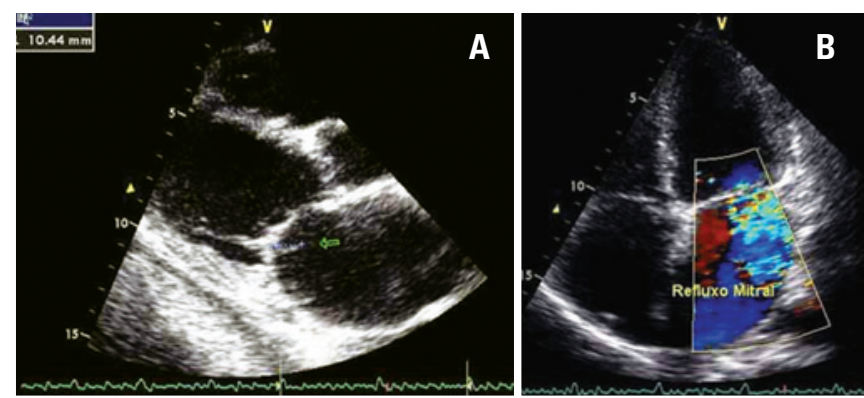

Figure 2. (A) Parasternal longitudinal section. Two-dimensional echocardiogram with filament vegetation on atrial face of the mitral valve posterior cuspid leaflet (arrow). (B) Apical section indicating important mitral reflux. Color flow mapping (blue área) covering more than a half of the enlarged left atrium 
Because ultrasound methodology did not achieve clear results, to complete the investigation a magnetic resonance of the right limb was done and showed in his right tight a substantial edema besides thickness and diffuse subcutaneous enhancement in his right leg, which suggested an inflammatory/infectious process. The patient's leg muscle bundle showed an edema mainly in anterior compartment and the medial portion of the deep posterior compartment which was unspecific. In addition, a subaponeurotic liquid accumulation of medial gastrocnemius muscle with a thickness of up to $5.0 \mathrm{~mm}$ was seen (Figure 3).

During his hospitalization acute sepsis was controlled, but myeloma activity (Table 2 ) and renal insufficiency

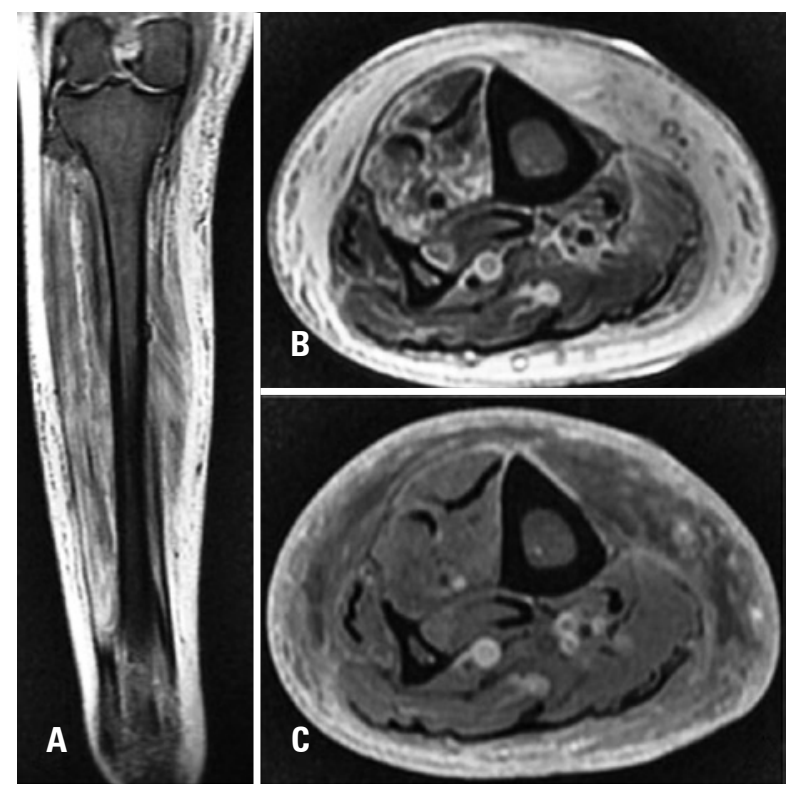

Figure 3. Magnetic ressonance of the lower limb (leg): STIR coronal images (A) T2FS axial (B) axial with contrast T1FS (C) indicating: edema, thickness, diffuse subcutaneous enhancement suggesting a inflammatory/infectious process. Edema in the leg muscle bundle mainly in the anterior and posterior deep compartments was noted

Table 2. Laboratory tests related to patient progression

\begin{tabular}{|c|c|}
\hline Tests & Results \\
\hline Myelogram & $50 \%$ of atypical plasma \\
\hline Immunoelectrophoresis (blood) & $\begin{array}{l}\text { Monoclonal component - IgG kappa } \\
\text { lgG=1,770mg/dL (700.0-1,600.0mg/dL) } \\
\text { kappa }=733 \mathrm{mg} / \mathrm{dL}(170.0-370.0 \mathrm{mg} / \mathrm{dL})\end{array}$ \\
\hline Immunofixation (urine) & $\begin{array}{l}\text { Monoclonal component - lgG kappa, } \\
\text { followed by clonal fractation of kappa free } \\
\text { light-chain } \\
\text { Protein dosage: } 0.83 \mathrm{~g} / \mathrm{L}(<0.05 \mathrm{~g} / \mathrm{L})\end{array}$ \\
\hline $\begin{array}{l}\text { Kappa Chain and Relation lambda light } \\
\text { (blood) }\end{array}$ & $116.71(0.26-1.65)$ \\
\hline Protein (24 hours urine) & $1.58 \mathrm{~g}(0.04-0.23 \mathrm{~g})$ \\
\hline Bence Jones protein & Positive \\
\hline
\end{tabular}

progressed being (Figure 4) associated with the rupture of the chordae tendineae, increase of mitral regurgitation, pulmonary pressure having as outcome the death of the patient.

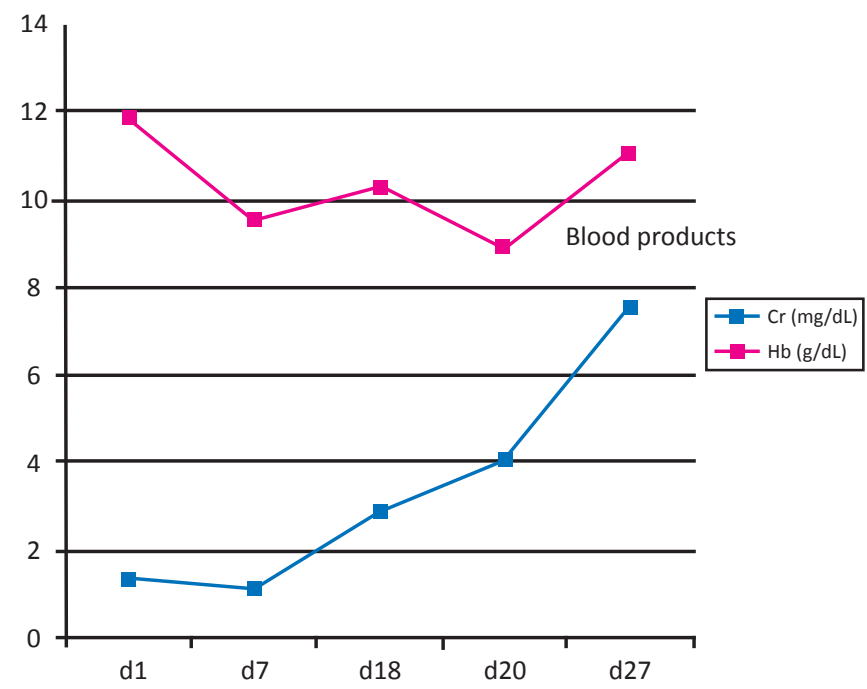

Figure 4. Disease symptoms-related laboratory parameters

\section{DISCUSSION}

IE is a infection caused by microorganisms of the endocardial surface of the heart leading to vegetation formation ${ }^{(5)}$. Longevity increase has raised the frequency of degenerative valvular diseases, placement of prosthetic valves, and exposure to nosocomial bacteremia. The median age of those diagnosed with IE has changed: it was 30 to 40 years during preantibiotic era, and after this period it increased to 47 to 69 years ${ }^{(5)}$. This change was also observed in the frequency of the disease so that in general population it occurs in $3-10$ cases per 100,000 person-years while among those between 70 and 80 years old its occurrence is reported as 14.5 cases per 100,000 person-years ${ }^{(6)}$.

Mitral-valve prolapsed is the most common predisposition factor among the cardiovascular lesions ${ }^{(5,6)}$, however, $50 \%$ of diagnosed patients had no previous valvular disease ${ }^{(6)}$.

Streptococcus viridans is described as the most frequent etiologic agent in patients with IE, however, current epidemiological studies reported an increase of Stafilococcus aureus frequency, present in $31 \%$ of cases $^{(5-7)}$, so keeping the prominence of Gram-positive strains $(>80 \%)$ in this disease ${ }^{(8)}$. IE caused by the Gram-negative bacteria is uncommon and when it occurs it is frequently caused by the HACEK group 
(Haemophilus spp, Actinobacillus actinomycetemcomitans, Cardiobacterium hominis, Eikenella corrodens, Kingella spp). Escherichia coli and the Pseudomonas aueriginosa that do not belong to HACEK group are present in $1.8 \%$ of cases, respectively $29 \%$ and $22 \%{ }^{(7)}$.

The clinical presentation of IE varies depending on the infectious agent and the affected heart valve. When cardiac symptoms are found they are associated to a poor prognosis. Cardiac insufficient (CI) is often caused by the valvar damage. Although in rare cases emboli from the cardiac vegetation may cause myocardial ischemia ${ }^{(5)}$.

Embolic events are responsible for fungal aneurysm in the central nervous system, osteomuscular disease, arthropathy, and renal insufficiency in which case it is found an immune complex deposition. Vasculitis occurs in some cases ${ }^{(5,6)}$.

According to a classical point of view surgery is indicated when complicated endocarditis does not respond to clinical treatment, however, neither by the prognosis implied or by the fragility of the basic disease ${ }^{(5,6)}$.

Endocarditis frequency in MM patients is rare, and when reported it is secondary to Gram-positive agents, which constitute the main infectious agents associated to this hematologic neoplasia ${ }^{(5)}$.

Historically, up to the 1980 s the already well-know infectious processes responsible for the high mortality related to MM were described as being caused only by Gram-positive agents, mainly the encapsulated ones (pneumococus, meningococus and Haemophilus influenzae) and Staphylococcus aureus. However, by that time an increase in infections caused by Gram-negative strains in these patients was also observed especially caused by enterobacteriaceae and Pseudomonas aeruginosa. Such infections were associated to the development of chemotherapy, manipulations due to this kind of therapy, and duration of hospital stay ${ }^{(8,9)}$. Most of reported infections were found in urinary tract and lungs ${ }^{(3,7,8)}$.

Several factors are associated with infection in MM. This disease is often seen in elderly patients who were submitted to chemotherapy which alone may cause an immunosuppression, mainly humoral, and might be influenced by a chronic renal insufficiency due to the basic disease $^{(3)}$.

Immunodeficiency in myeloma as well as other factors related to a predisposition to infection and renal insufficiency are multifactorial. More specifically it means that, at the same time that plasma cells secrete a monoclonal immunoglobulin at expense of the production of other immunoglobulin chains leading to hypogammaglobulinemia, there is a functional and numerical abnormality of dendritic cells and T-cells with dysfunction of NK cells. The mechanism by which this second event occurs is not clearly defined in the literature And may be intensified by chemotherapy leading to agranulocytosis, impairing the immunosupression status as previously described ${ }^{(3,8,10)}$.

In this case the occurrence of a rare subtype of IE caused by Gram-negative (pseudomonas) was highlighted as it occurred in an elderly patient diagnosed with $\mathrm{MM}$ who did not have a previous interventionial approach or hospitalization history, and was receiving chemotherapy. The patient presented complication associated to the infection disease (chordae tendineae rupture) and progression of the hematologic neoplastic disease.

\section{REFERENCES}

1. Pratt G, Goodyear 0, Moss P. Immunodeficiency and immunotherapy in multiple myeloma. Br J Haematol. 2007;138(5):563-79.

2. Cesana C, Nosari AM, Klersy C, Miqueleiz S, Rossi V, Ferrando P, et al. Risk factors for the development of bacterial infections in multiple myeloma treated with two different vincristine-adriamycin- dexamethasone schedules. Haematologica. 2003;88(9):1022-8.

3. Kalambokis GN, Christou L, Tsianos EV. Multiple myeloma presenting with an acute bacterial infection. Int J Lab Hematol. 2009;31 (4):375-83.

4. Fukuzuwa S, Ozawa S, Shimada K, Katagiri M. Multiple myeloma complicated with streptococcal endocarditis successfully treated by mitral valve replecement. Intern Med. 1994;33(1):13 -7.

5. Mylonakis E, Calderwood SB. Infective endocarditis in adults. N Engl J Med. 2001;345(18):1318-30

6. Tornos P, Gonzalez-Alujas T, Thuny F, Habib G. Infective endocarditis: the European viewpoint. Curr Probl Cardiol. 2011;36(5):175-222.

7. Cervera C, Castañeda X, Pericas JM, Del Rio A, de la Maria CG, Mestres C et al. Clinical utility of daptomycin in infective endocarditis caused by Grampositive cocci. Int J Antimicrob Agents. 2011;38(5):365-70.

8. Doughney KB, Williams DM, Penn RL. Multiple myeloma: infectious complications. South Med J. 1988;81(7):855-8.

9. Espersen F, Birgens HS, Hertz JB, Drivsholm A. Current patterns of bacterial infection in myelomatosis. Scand J Infect Dis. 1984;16(2):169-73.

10. Dimopoulos MA, Terpos E, Chanan-Khan A, Leung N, Ludwig H, Jagannath $S$, et al. Renal impairment in patients with multiple myeloma: a consensus statement on behalf of the International Myeloma Working Group. J Clin Oncol. 2010;28(33):4976-84. 